\title{
2-(2,4-Difluorophenyl)-1,3-bis(1,2,4-triazol-1-yl)propan-2-ol derivatives: synthesis, antifungal evaluation and QSAR studies by Hansch analysis
}

\section{Ruchita Ohlan, Sucheta Ohlan, Vikramjeet Judge, Rakesh Narang, Munish Ahuja, and Balasubramanian Narasimhan*}

Faculty of Pharmaceutical Sciences, Guru Jambheshwar University of Science and Technology, Hisar 125001, India

E-mail:naru2000us@yahoo.com

\begin{abstract}
A variety of fluconazole derivatives were synthesized by reacting the alcoholic function of fluconazole with an acid chloride of a variety of aliphatic and aromatic organic acids. The acid chlorides were prepared by reaction of the corresponding organic acids with thionyl chloride. The synthesized compounds were evaluated for their in vitro antifungal activity against $C$. albicans and $A$. niger and the results indicated that the compounds 6, 11, and $\mathbf{1 5}$ are more active in comparison to the parent compound, fluconazole. Further quantitative structure activity relationship (QSAR) was applied on these fluconazole derivatives to understand the relationship between the biological activity and the structural features. The QSAR study indicated the importance of electronic parameters, the energy of the lowest unoccupied molecular orbital (LUMO) and the topological parameter ${ }^{2} \chi$, second order molecular connectivity index in contribution to the antifungal activity of the fluconazole derivatives. Excellent statistically significant models were developed by this approach $(r=0.85-0.89)$. The cross-validated $r^{2}\left(q^{2}\right)$, which is an indication of the predictive capability of the model, was also very good $\left(\mathrm{q}^{2}>0.5\right)$.
\end{abstract}

Keywords: Fluconazole derivatives, antifungal activity, QSAR, LOO method

\section{Introduction}

In recent years fungal infections have emerged as a major cause of disease and mortality, in part as a consequence of the increase in the acquired immunodeficiency syndrome (AIDS) ${ }^{1-3}$. The easily gained resistance is the main problem encountered in developing safe and efficient antifungals. There are effective antifungal agents on the market, but each drug carries several drawbacks. The presently marketed antifungal drugs are either toxic (e.g. Amphotericin-B, $\mathrm{AMB}$ ) or are becoming ineffective due to the appearance of resistant strains (e.g. Flucytocine). 
AMB remains the gold standard drug for life threatening fungal infection, but its use is limited due to its severe toxicity ${ }^{4-5}$.

The azole antifungals may be regarded as a new class of truly effective drugs that inhibit fungi by blocking the biosynthesis of ergosterol, a major component of the fungal plasma membrane, by inhibiting the cytochrome P-450 dependent enzyme lanosterol demethylase ${ }^{6-7}$. The most frequently used antifungal fluconazole possess a broad-spectrum activity and reduced toxicity compared to other antifungal drugs. Extensive use of fluconazole resulted in the increase of the number of fluconazole resistant fungi strains ${ }^{8-13}$.

The quantitative structure-activity relationship (QSAR) study is a useful tool for a rational search of bioactive compounds. A QSAR study describes a definite role in a quantitative term of a structural feature in the molecule with a definite contribution to the activity of a particular physicochemical property of the structural feature. Thus, QSAR studies have a predictive ability and simultaneously provide deeper insight into the mechanism of drug receptor intractions. ${ }^{14}$

In view of the above and in continuation of our studies on QSAR in describing biological activity ${ }^{15-21}$, the present paper reports on the QSAR studies on antifungal activity of newly synthesized fluconazole derivatives for the first time.

\section{Results and Discussion}

The synthesis of fluconazole [2-(2,4-difluorophenyl)-1,3-bis(1,2,4-triazol-1-yl)propan-2-ol] derivatives was carried out as outlined in Scheme 1 and Scheme 2. The key intermediate acid chloride was prepared by the reaction of the corresponding acids with thionyl chloride/phosphorus pentachloride. The acid chlorides were reacted with fluconazole to yield their corresponding esters. The esters were confirmed by their high Rf value and low melting point. The spectral data were found in agreement with the assigned molecular structure. The physicochemical characteristics of the synthesized compounds are presented in Table1. 


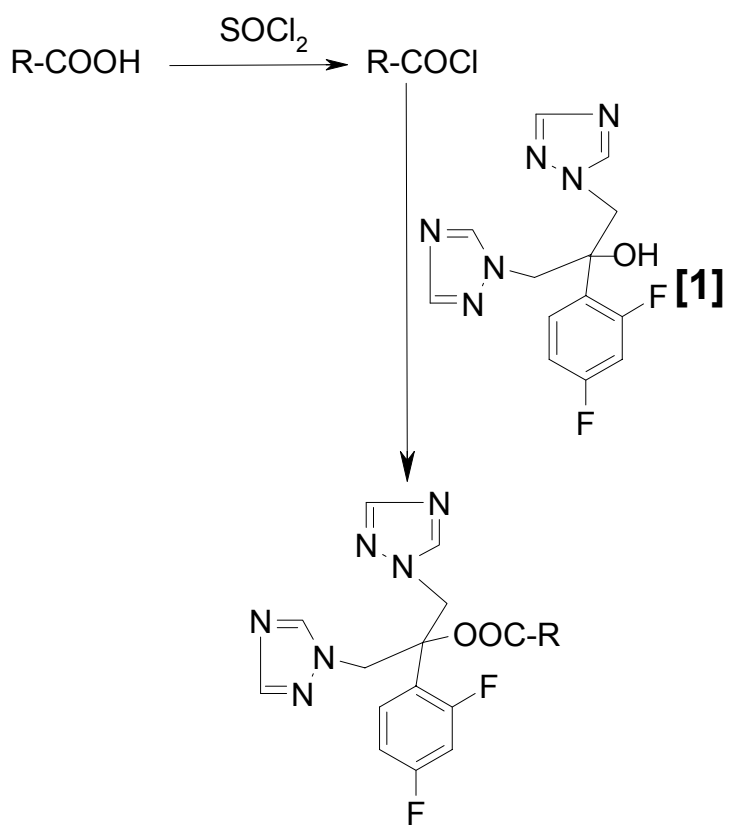

$[2-3,6-9,15]$

$2 ; \mathrm{R}=-\mathrm{CH}_{2}\left(\mathrm{CH}_{2}\right)_{9} \mathrm{CH}_{3}$

3; $\mathrm{R}=-\mathrm{CH}=\mathrm{CH}-\mathrm{CH}=\mathrm{CH}-\mathrm{CH}_{3}$

6; $\mathrm{R}=-\mathrm{CH}_{2}\left(\mathrm{CH}_{2}\right)_{15} \mathrm{CH}_{3}$

$7 ; \mathrm{R}=-\mathrm{CH}_{2}\left(\mathrm{CH}_{2}\right)_{13} \mathrm{CH}_{3}$

8; $\mathrm{R}=-\mathrm{C} \mathrm{H}_{2} \mathrm{CH}_{3}$

9; $\mathrm{R}=-\mathrm{CH}_{2} \mathrm{CH}_{2} \mathrm{CH}_{3}$

$15 ; \mathrm{R}=-\mathrm{CH}_{2}\left(\mathrm{CH}_{2}\right)_{11} \mathrm{CH}_{3}$

Scheme 1. Scheme for synthesis of aliphatic fluconazole derivatives.

The in vitro antifungal activity of fluconazole derivatives has been investigated against Candida albicans (CA) and Aspergillus niger (AN). The minimum inhibitory concentration (MIC) was determined by means of a standard two-fold dilution method ${ }^{22}$ using Sabouraud dextrose broth. Most of the synthesized compounds have been found to delineate profound antifungal activity compared to the parent drug, fluconazole. Fluconazolyl stearate (6), fluconazolyl veratrate (11) and fluconazolyl myristate (15) were found to be more active than the parent compound, fluconazole. The antifungal screening results depicted in Table 1, reveals that the reported compounds showed a remarkable antifungal effect.

\section{A. niger $>$ C. albicans}

In order to deduce the correlation of the observed antifungal activity, in terms of the MIC $\left(\mu \mathrm{M} \mathrm{mL}^{-1}\right)$ of the reported compounds with different structural parameters, a systemic QSAR investigation has been carried out using the model proposed by Hansch et al. ${ }^{23}$ The activity data (pMIC) representing the concentration of compound that inhibited the visible growth in various fungal species, was used as dependent variable to get a linear relationship in the QSAR model. 
These were correlated with different molecular descriptors like the log of the octanol-water partition coefficient $(\log \mathrm{P})^{24}$, the molar refractivity $(\mathrm{MR})^{25}$, Kier's molecular connectivity $\left({ }^{0} \chi\right.$, $\left.{ }^{0} \chi^{\mathrm{v}},{ }^{1} \chi,{ }^{1} \chi^{\mathrm{v}},{ }^{2} \chi,{ }^{2} \chi^{\mathrm{v}}\right)$ and shape $\left(\kappa_{1}, \kappa \alpha_{1}\right)$ topological indices ${ }^{26}$, the Randic topological index $(\mathrm{Ra})^{27}$, the Balban topological index $(\mathrm{J})^{28}$, the Wiener topological index $(\mathrm{W})^{29}$, the Total energy $(\mathrm{Te})$, energies of the highest occupied molecular orbital (HOMO) and the lowest unoccupied molecular orbital (LUMO) $)^{30}$, the dipole moment $(\mu)$, the electronic energy (Ele.E), the nuclear energy (Nu.E) and the molecular surface area (SA) ${ }^{31}$. The values of the selected descriptors used in the regression analysis are presented in Table 2. The above-mentioned parameters were calculated for the lowest energy conformers of the compounds in the series using the software TSAR 3D version. ${ }^{32}$

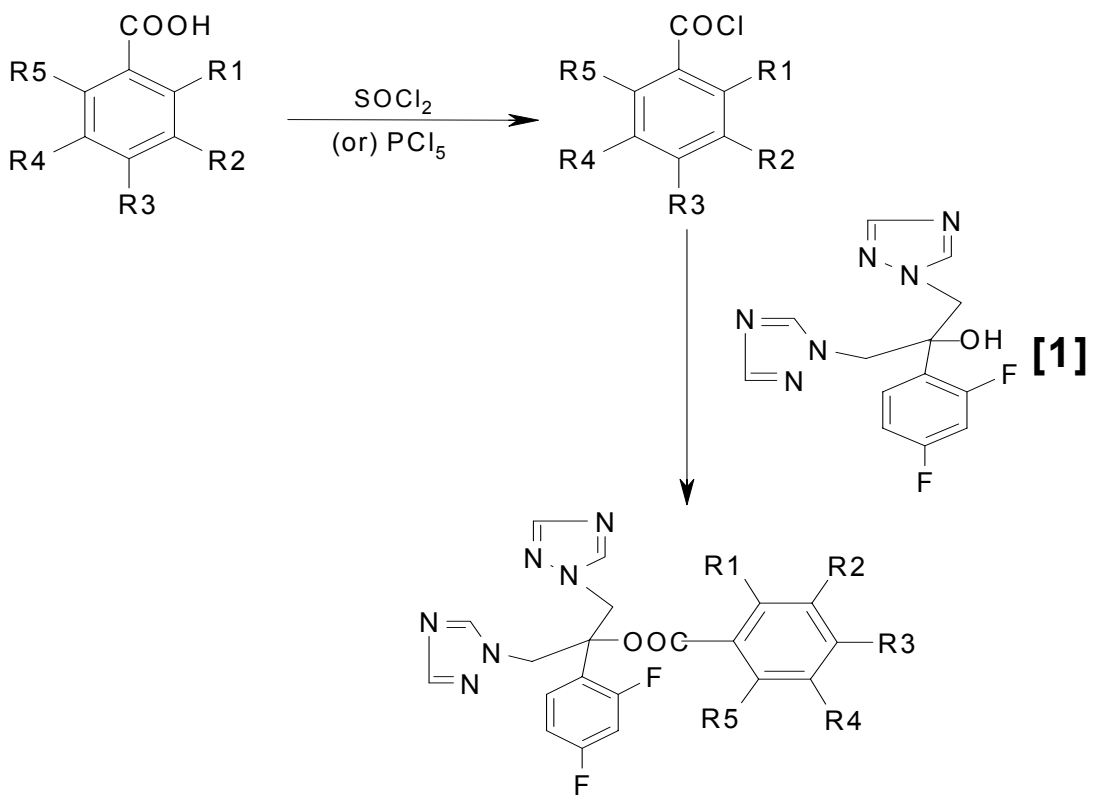

$[4-5,10-14,16-20]$

$4 ; \mathrm{R}_{1}=\mathrm{OH}, \mathrm{R}_{2}, \mathrm{R}_{3}, \mathrm{R}_{4}, \mathrm{R}_{5}=\mathrm{H}$

5; $\mathrm{R}_{1}, \mathrm{R}_{2}, \mathrm{R}_{3}, \mathrm{R}_{4}, \mathrm{R}_{5}=\mathrm{H}$

10; $\mathrm{R}_{1}, \mathrm{R}_{2}, \mathrm{R}_{3}, \mathrm{R}_{4}, \mathrm{R}_{5}=\mathrm{H}(\mathrm{Ar}-\mathrm{CH}=\mathrm{CH}-)$

11; $\mathrm{R}_{2}, \mathrm{R}_{3}=\mathrm{OCH}_{3}, \mathrm{R}_{1}, \mathrm{R}_{4}, \mathrm{R}_{5}=\mathrm{H}$

12; $\mathrm{R}_{3}=\mathrm{NO}_{2}, \mathrm{R}_{1}, \mathrm{R}_{2}, \mathrm{R}_{4}, \mathrm{R}_{5}=\mathrm{H}$

13; $\mathrm{R}_{3}=\mathrm{Cl}, \mathrm{R}_{1}, \mathrm{R}_{2}, \mathrm{R}_{4}, \mathrm{R}_{5}=\mathrm{H}$

14; $\mathrm{R}_{1}=\mathrm{Cl}, \mathrm{R}_{2}, \mathrm{R}_{3}, \mathrm{R}_{4}, \mathrm{R}_{5}=\mathrm{H}$

16; $\mathrm{R}_{1}=\mathrm{Br}, \mathrm{R}_{2}, \mathrm{R}_{3}, \mathrm{R}_{4}, \mathrm{R}_{5}=\mathrm{H}$

17; $\mathrm{R}_{2}=\mathrm{NO}_{2}, \mathrm{R}_{1}, \mathrm{R}_{3}, \mathrm{R}_{4}, \mathrm{R}_{5}=\mathrm{H}$

18; $\mathrm{R}_{3}=\mathrm{NH}_{2}, \mathrm{R}_{1}, \mathrm{R}_{2}, \mathrm{R}_{4}, \mathrm{R}_{5}=\mathrm{H}$

19; $\mathrm{R}_{2}=\mathrm{OCH}_{3}, \mathrm{R}_{1}, \mathrm{R}_{3}, \mathrm{R}_{4}, \mathrm{R}_{5}=\mathrm{H}$

20; $\mathrm{R}_{3}=\mathrm{OCH}_{3}, \mathrm{R}_{1}, \mathrm{R}_{2}, \mathrm{R}_{4}, \mathrm{R}_{5}=\mathrm{H}$

Scheme 2. Scheme for the synthesis of aromatic fluconazole derivatives. 
Table 1. Physicochemical properties and antifungal activity of Fluconazole derivatives

\begin{tabular}{|c|c|c|c|c|c|c|c|}
\hline \multirow[t]{2}{*}{ Com. } & \multirow{2}{*}{ Mol. formula } & \multirow{2}{*}{ M. Wt } & \multirow{2}{*}{ M.p. } & \multirow{2}{*}{$\mathrm{Rf}\left(\mathrm{CHCl}_{3}\right)$} & \multirow{2}{*}{$\%$ Yield } & \multicolumn{2}{|c|}{$\mathrm{pMIC}(\mu \mathrm{M} / \mathrm{mL})$} \\
\hline & & & & & & $\mathrm{CA}$ & $\mathrm{AN}$ \\
\hline 1 & $\mathrm{C}_{13} \mathrm{H}_{12} \mathrm{~F}_{2} \mathrm{~N}_{6} \mathrm{O}$ & 306.30 & $138-140$ & 0.151 & --- & 2.49 & 2.64 \\
\hline 2 & $\mathrm{C}_{25} \mathrm{H}_{34} \mathrm{~F}_{2} \mathrm{~N}_{6} \mathrm{O}_{2}$ & 488.62 & $77-80$ & 0.268 & 56.50 & 2.59 & 2.75 \\
\hline 3 & $\mathrm{C}_{19} \mathrm{H}_{18} \mathrm{~F}_{2} \mathrm{~N}_{6} \mathrm{O}_{2}$ & 400.3 & $176-179$ & 0.148 & 37.86 & 2.51 & 2.60 \\
\hline 4 & $\mathrm{C}_{20} \mathrm{H}_{16} \mathrm{~F}_{2} \mathrm{~N}_{6} \mathrm{O}_{3}$ & 426.42 & $80-83$ & 0.407 & 45.60 & 2.35 & 2.83 \\
\hline 5 & $\mathrm{C}_{20} \mathrm{H}_{16} \mathrm{~F}_{2} \mathrm{~N}_{6} \mathrm{O}_{2}$ & 410.3 & $96-99$ & 0.341 & 42.52 & 2.44 & 2.71 \\
\hline 6 & $\mathrm{C}_{31} \mathrm{H}_{46} \mathrm{~F}_{2} \mathrm{~N}_{6} \mathrm{O}_{2}$ & 572.78 & $115-118$ & 0.281 & 56.70 & 2.76 & 2.96 \\
\hline 7 & $\mathrm{C}_{29} \mathrm{H}_{42} \mathrm{~F}_{2} \mathrm{~N}_{6} \mathrm{O}_{2}$ & 544.73 & $97-100$ & 0.271 & 53.42 & 2.57 & 2.94 \\
\hline 8 & $\mathrm{C}_{16} \mathrm{H}_{16} \mathrm{~F}_{2} \mathrm{~N}_{6} \mathrm{O}_{2}$ & 362.3 & $85-88$ & 0.148 & 30.68 & 2.52 & 2.65 \\
\hline 9 & $\mathrm{C}_{17} \mathrm{H}_{18} \mathrm{~F}_{2} \mathrm{~N}_{6} \mathrm{O}_{2}$ & 376.3 & $145-147$ & 0.202 & 29.27 & 2.48 & 2.67 \\
\hline 10 & $\mathrm{C}_{22} \mathrm{H}_{18} \mathrm{~F}_{2} \mathrm{~N}_{6} \mathrm{O}_{2}$ & 436.46 & $170-173$ & 0.364 & 41.70 & 2.54 & 2.84 \\
\hline 11 & $\mathrm{C}_{22} \mathrm{H}_{20} \mathrm{~F}_{2} \mathrm{~N}_{6} \mathrm{O}_{4}$ & 470.30 & $70-73$ & 0.643 & 48.96 & 2.65 & 2.85 \\
\hline 12 & $\mathrm{C}_{20} \mathrm{H}_{15} \mathrm{~F}_{2} \mathrm{~N}_{7} \mathrm{O}_{4}$ & 455.42 & $65-68$ & 0.461 & 41.62 & 2.06 & 2.86 \\
\hline 13 & $\mathrm{C}_{20} \mathrm{H}_{15} \mathrm{~F}_{2} \mathrm{~N}_{6} \mathrm{ClO}_{2}$ & 444.87 & $70-73$ & 0.202 & 45.34 & 2.29 & 2.73 \\
\hline 14 & $\mathrm{C}_{20} \mathrm{H}_{15} \mathrm{~F}_{2} \mathrm{~N}_{6} \mathrm{ClO}_{2}$ & 444.87 & $72-75$ & 0.122 & 38.69 & 2.41 & 2.73 \\
\hline 15 & $\mathrm{C}_{27} \mathrm{H}_{38} \mathrm{~F}_{2} \mathrm{~N}_{6} \mathrm{O}_{2}$ & 516.68 & $115-118$ & 0.244 & 60.20 & 2.54 & 2.92 \\
\hline 16 & $\mathrm{C}_{20} \mathrm{H}_{15} \mathrm{~F}_{2} \mathrm{~N}_{6} \mathrm{BrO}_{2}$ & 489.32 & $167-170$ & 0.298 & 54.62 & 2.50 & 2.73 \\
\hline 17 & $\mathrm{C}_{20} \mathrm{H}_{15} \mathrm{~F}_{2} \mathrm{~N}_{7} \mathrm{O}_{4}$ & 455.42 & $45-48$ & 0.521 & 32.43 & 2.06 & 2.77 \\
\hline 18 & $\mathrm{C}_{20} \mathrm{H}_{17} \mathrm{~F}_{2} \mathrm{~N}_{7} \mathrm{O}_{2}$ & 425.42 & $41-44$ & 0.521 & 37.02 & 2.53 & 2.73 \\
\hline 19 & $\mathrm{C}_{21} \mathrm{H}_{18} \mathrm{~F}_{2} \mathrm{~N}_{6} \mathrm{O}_{3}$ & 440.45 & $130-133$ & 0.647 & 22.80 & 2.55 & 2.85 \\
\hline 20 & $\mathrm{C}_{21} \mathrm{H}_{18} \mathrm{~F}_{2} \mathrm{~N}_{6} \mathrm{O}_{3}$ & 440.45 & $119-122$ & 0.657 & 29.43 & 2.40 & 2.85 \\
\hline
\end{tabular}

Using these above data, a correlation matrix was calculated to find the correlation as well as the colinearity between the descriptors (Table 3). A high interrelationship was observed between ${ }^{0} \chi$ and ${ }^{1} \chi(\mathrm{r}=0.999)$ as well the low interrelationship was observed between ${ }^{0} \chi$ and LUMO $(\mathrm{r}=$ $0.044)$.

The data presented in Table- 3 demonstrated the high colinearity between the parameters $(\mathrm{r}>$ 0.8 ) except with the LUMO. This high colinearity indicated that these parameters couldn't be combined to get multiple linear regression (MLR) models. If combined, it may result in change in signs of the coefficients, a change in the values of the previous coefficient, the change of a significant variable into an insignificant one or an increase in standard error of the estimate on addition of an additional parameter to the model. ${ }^{33}$

Model-1 is developed to predict the antifungal activity of the fluconazole derivatives against C. albicans. The statistically significant Eq-1 shows a positive correlation with the LUMO as shown below. 
Table 2. Molecular descriptors of fluconazole derivatives used in regression analysis

\begin{tabular}{cccccccccc}
\hline Comp. & $\log \mathrm{P}$ & $\mathrm{MR}$ & ${ }^{0} \chi$ & ${ }^{0} \chi^{\mathrm{v}}$ & ${ }^{1} \chi$ & ${ }^{1} \chi^{\mathrm{v}}$ & ${ }^{2} \chi$ & ${ }^{2} \chi^{\mathrm{v}}$ & LUMO \\
\hline $\mathbf{1}$ & 0.79 & 76.90 & 15.58 & 11.34 & 10.57 & 6.39 & 9.87 & 4.88 & -0.79 \\
$\mathbf{2}$ & 5.11 & 132.09 & 24.93 & 20.28 & 17.02 & 12.34 & 14.50 & 8.90 & -0.65 \\
$\mathbf{3}$ & 2.55 & 106.69 & 20.69 & 15.52 & 14.02 & 8.65 & 12.38 & 6.15 & -1.05 \\
$\mathbf{4}$ & 2.54 & 107.92 & 21.85 & 15.97 & 14.97 & 9.08 & 13.68 & 6.75 & -1.03 \\
$\mathbf{5}$ & 2.83 & 106.23 & 20.98 & 15.60 & 14.56 & 8.94 & 13.15 & 6.60 & -0.92 \\
$\mathbf{6}$ & 7.49 & 159.70 & 29.18 & 24.53 & 20.02 & 15.34 & 16.62 & 11.02 & -0.60 \\
$\mathbf{7}$ & 6.70 & 150.49 & 27.76 & 23.11 & 19.02 & 14.34 & 15.91 & 10.31 & -0.65 \\
$\mathbf{8}$ & 1.54 & 90.68 & 18.57 & 13.92 & 12.52 & 7.84 & 11.29 & 5.67 & -0.66 \\
$\mathbf{9}$ & 1.94 & 95.28 & 19.28 & 14.63 & 13.02 & 8.34 & 11.67 & 6.07 & -0.65 \\
$\mathbf{1 0}$ & 3.24 & 116.47 & 22.39 & 16.75 & 15.54 & 9.60 & 13.96 & 7.01 & -0.81 \\
$\mathbf{1 1}$ & 2.26 & 109.62 & 22.72 & 16.34 & 15.36 & 9.22 & 14.28 & 6.94 & -1.01 \\
$\mathbf{1 2}$ & 2.78 & 113.55 & 23.42 & 16.78 & 15.86 & 9.44 & 14.67 & 7.04 & -2.00 \\
$\mathbf{1 3}$ & 3.35 & 111.03 & 21.85 & 16.72 & 14.95 & 9.45 & 13.78 & 7.21 & -1.18 \\
$\mathbf{1 4}$ & 4.46 & 106.32 & 21.14 & 16.01 & 14.49 & 9.01 & 13.18 & 6.68 & -1.01 \\
$\mathbf{1 5}$ & 5.90 & 141.29 & 26.35 & 21.70 & 18.02 & 13.34 & 15.21 & 9.61 & -0.65 \\
$\mathbf{1 6}$ & 3.62 & 113.85 & 21.85 & 17.52 & 14.97 & 9.86 & 13.68 & 7.59 & -0.82 \\
$\mathbf{1 7}$ & 2.78 & 113.55 & 23.42 & 16.78 & 15.86 & 9.44 & 14.69 & 7.04 & -1.73 \\
$\mathbf{1 8}$ & 2.05 & 110.93 & 21.85 & 16.10 & 14.95 & 9.14 & 13.78 & 6.86 & -0.69 \\
$\mathbf{1 9}$ & 2.58 & 112.69 & 22.55 & 16.93 & 15.49 & 9.47 & 13.96 & 6.97 & -0.93 \\
$\mathbf{2 0}$ & 2.64 & 111.93 & 22.55 & 16.72 & 15.49 & 9.27 & 13.94 & 6.64 & -1.29 \\
\hline
\end{tabular}

Table 3. Correlation matrix for antifungal activity of fluconazole derivatives against $C$. albicans

\begin{tabular}{|c|c|c|c|c|c|c|c|c|c|c|c|c|c|c|}
\hline & pMICca & $\log \mathrm{P}$ & MR & ${ }^{0} \chi$ & ${ }^{0} \chi^{\mathrm{v}}$ & ${ }^{1} \chi$ & ${ }^{1} \chi^{\mathrm{v}}$ & ${ }^{2} \chi$ & ${ }^{2} \chi^{v}$ & $\kappa_{1}$ & $\kappa_{2}$ & $\kappa \alpha_{1}$ & LUMO & pMICan \\
\hline pMICca & 1.000 & 0.348 & 0.323 & 0.213 & 0.346 & 0.224 & 0.387 & 0.072 & 0.364 & 0.285 & 0.393 & 0.339 & 0.874 & 1.000 \\
\hline $\log p$ & & 1.000 & 0.937 & 0.886 & 0.951 & 0.891 & 0.957 & 0.788 & 0.955 & 0.915 & 0.932 & 0.934 & 0.281 & 0.660 \\
\hline MR & & & 1.000 & 0.982 & 0.994 & 0.985 & 0.984 & 0.918 & 0.982 & 0.992 & 0.974 & 0.988 & 0.187 & 0.783 \\
\hline${ }^{0} \chi$ & & & & 1.000 & 0.971 & 0.999 & 0.949 & 0.968 & 0.951 & 0.990 & 0.939 & 0.971 & 0.044 & 0.834 \\
\hline${ }^{0} \chi^{\mathrm{v}}$ & & & & & 1.000 & 0.971 & 0.994 & 0.892 & 0.993 & 0.988 & 0.979 & 0.993 & 0.227 & 0.767 \\
\hline${ }^{1} \chi$ & & & & & & 1.000 & 0.949 & 0.969 & 0.951 & 0.987 & 0.937 & 0.968 & 0.059 & 0.839 \\
\hline${ }^{1} \chi^{v}$ & & & & & & & 1.000 & 0.852 & 0.996 & 0.979 & 0.990 & 0.993 & 0.289 & 0.745 \\
\hline${ }^{2} \chi$ & & & & & & & & 1.000 & 0.867 & 0.923 & 0.825 & 0.882 & -0.118 & 0.854 \\
\hline${ }^{2} \chi^{v}$ & & & & & & & & & 1.000 & 0.973 & 0.974 & 0.985 & 0.270 & 0.752 \\
\hline$\kappa_{1}$ & & & & & & & & & & 1.000 & 0.978 & 0.994 & 0.135 & 0.799 \\
\hline$\kappa_{2}$ & & & & & & & & & & & 1.000 & 0.992 & 0.278 & 0.730 \\
\hline$\kappa \alpha_{1}$ & & & & & & & & & & & & 1.000 & 0.210 & 0.769 \\
\hline LUMO & & & & & & & & & & & & & 1.000 & -0.054 \\
\hline
\end{tabular}




\section{QSAR model for antifungal activity against $C$. albicans}

$$
\begin{array}{r}
\text { pMICca }=0.404 \mathrm{LUMO}+2.848 \\
\mathrm{n}=20 \quad \mathrm{r}=0.874 \mathrm{r}^{2}=0.764 \mathrm{q}^{2}=0.715 \mathrm{~F}=58.43 \quad \mathrm{~s}=0.085
\end{array}
$$

$\mathrm{n}$ is the number of data points, $\mathrm{r}$ is the multiple correlation co-efficient, $\mathrm{s}$ is the standard error of estimate, F represents Fisher ratio between the variances of observed and predicted activities, $\mathrm{q}^{2}$ is the cross validated $\mathrm{r}^{2}$ obtained by the Leave one out (LOO) method.

The electronic parameter LUMO which denote the energy of the lowest unoccupied molecular orbital, directly relates to the electron affinity and characterizes the susceptibility of the molecule towards an attack by nucleophiles. ${ }^{34}$

A positive correlation with the LUMO indicates that the magnitude of the antifungal activity of the fluconazole derivatives is directly proportional to the LUMO values. This was evidenced by the LUMO values of compounds 6, 11, and 15 (LUMO = -0.60, -1.01, -0.65, see Table 2) which were higher than those of other compounds and which are highly active with pMICca values of 2.76, 2.65, 2.54 (Table 1) respectively. Similarly, the compounds $\mathbf{1 2}$ and $\mathbf{1 7}$ having low LUMO values ( -2.00 and -1.73 (Table 2 ) respectively) have minimal antifungal activity against C. albicans $\left(\mathrm{pMIC}_{\mathrm{ca}}=2.06\right.$ and 2.06 respectively). The presence of an electron withdrawing group $\mathrm{NO}_{2}$ in compounds 12 and 17 may be responsible for their low LUMO value. A biparametric model for antifungal activity of the title compounds was developed using the second order molecular connectivity index $\left({ }^{2} \chi\right)$ and the energy of the lowest unoccupied molecular orbital (Eq. 2).

\section{QSAR model for antifungal activity against $C$. albicans}

$$
\mathrm{pMIC}_{\mathrm{ca}}=0.019^{2} \chi+0.414 \mathrm{LUMO}+2.587
$$

$\mathrm{n}=20 \mathrm{r}=0.892 \mathrm{r}^{2}=0.796 \mathrm{q}^{2}=0.606 \quad \mathrm{~F}=33.14 \mathrm{~s}=0.081$

The combination of the LUMO and ${ }^{2} \chi$ resulted in a very low increase in the $r$ value i.e. $r=$ 0.874 (Eq-1) to $r=0.892($ Eq-2). The interrelationships between the above parameters are very low $(r=-0.118$ Table-3). Looking at this interrelationship, it appears that there should be a significant increase in the r-value, whereas Eq.2 does not represent the above fact.

The trend may be explained by the existence of a Variance Inflation Factor (VIF). ${ }^{35}$ The VIF value was calculated from $1 / 1-r^{2}$, where $r^{2}$ is the squared multiple correlation coefficient of one parameter effect on the remaining parameter. VIF values greater than 5 indicate the presence of unacceptably large multicolinearity between parameters in the correlation. The VIF value of Eq2 is closer to $5(\mathrm{VIF}=4.87, \mathrm{Eq}-2)$ and may be responsible for the marginal increase in its $\mathrm{r}$ value. The model expressed by Eq-1 was cross validated by its high $\mathrm{q}^{2}$ value $\left(\mathrm{q}^{2}=0.715\right.$, Eq-1) obtained by the leave one out technique. The value of $\mathrm{q}^{2}$ greater than 0.5 is the basic requirement for qualifying a QSAR model to be a valid one. ${ }^{36}$ A good agreement between experimental and predicted data by Eq-1 is demonstrated by the low residual values observed in Table-4. Further, the predictive ability of Eq-1 is supported by the plot of $\mathrm{pMIC}_{\mathrm{ca}}$ observed verses $\mathrm{pMIC}$ ca predicted (Fig. 1). 
Further, the plot of $\mathrm{pMIC}_{\mathrm{ca}}$ observed verses residual $\mathrm{pMIC}_{\mathrm{ca}}$ indicates that no systemic error exists in the model development as the propagation of error is observed on both sides of zero ${ }^{21}$.

Table 4. Comparison of observed and predicted antifungal activities of fluconazole derivatives using best QSAR models

\begin{tabular}{ccccccc}
\hline \multirow{2}{*}{ Comp. } & \multicolumn{3}{c}{ pMICca using Eq.2 } & \multicolumn{3}{c}{ pMICan using Eq.3 } \\
\cline { 2 - 7 } & Obs. & Pre. & Res. & Obs. & Pre. & Res. \\
\hline $\mathbf{1}$ & 2.49 & 2.44 & 0.05 & 2.64 & 2.56 & 0.08 \\
$\mathbf{2}$ & 2.59 & 2.59 & 0.00 & 2.75 & 2.83 & -0.08 \\
$\mathbf{3}$ & 2.51 & 2.41 & 0.10 & 2.60 & 2.71 & -0.11 \\
$\mathbf{4}$ & 2.35 & 2.44 & -0.09 & 2.83 & 2.78 & 0.05 \\
$\mathbf{5}$ & 2.44 & 2.46 & -0.02 & 2.71 & 2.75 & -0.04 \\
$\mathbf{6}$ & 2.76 & 2.65 & 0.11 & 2.96 & 2.95 & 0.01 \\
$\mathbf{7}$ & 2.57 & 2.62 & -0.05 & 2.94 & 2.91 & 0.03 \\
$\mathbf{8}$ & 2.52 & 2.53 & -0.01 & 2.65 & 2.64 & 0.01 \\
$\mathbf{9}$ & 2.48 & 2.54 & -0.06 & 2.67 & 2.66 & 0.01 \\
$\mathbf{1 0}$ & 2.54 & 2.53 & 0.01 & 2.84 & 2.79 & 0.05 \\
$\mathbf{1 1}$ & 2.65 & 2.48 & 0.17 & 2.85 & 2.81 & 0.04 \\
$\mathbf{1 2}$ & 2.06 & 2.04 & 0.02 & 2.86 & 2.84 & 0.02 \\
$\mathbf{1 3}$ & 2.29 & 2.37 & -0.08 & 2.73 & 2.78 & -0.05 \\
$\mathbf{1 4}$ & 2.41 & 2.41 & 0.00 & 2.73 & 2.75 & -0.02 \\
$\mathbf{1 5}$ & 2.54 & 2.60 & -0.06 & 2.92 & 2.87 & 0.05 \\
$\mathbf{1 6}$ & 2.50 & 2.49 & 0.01 & 2.73 & 2.78 & -0.05 \\
$\mathbf{1 7}$ & 2.06 & 2.15 & -0.09 & 2.77 & 2.84 & -0.07 \\
$\mathbf{1 8}$ & 2.53 & 2.64 & -0.11 & 2.73 & 2.78 & -0.05 \\
$\mathbf{1 9}$ & 2.55 & 2.49 & 0.06 & 2.85 & 2.79 & 0.06 \\
$\mathbf{2 0}$ & 2.40 & 2.36 & 0.04 & 2.85 & 2.79 & 0.06 \\
\hline
\end{tabular}

Model-3 depicted in Eq-3 explains the correlation of antifungal activity of fluconazole derivatives against $A$. niger .

QSAR model for antifungal activity against $\boldsymbol{A}$. niger

$$
\begin{gathered}
\mathrm{pMIC}_{\mathrm{an}}=0.057^{2} \chi+2.003 \\
\mathrm{n}=20 \quad \mathrm{r}=0.854 \mathrm{r}^{2}=0.729 \mathrm{q}^{2}=0.645 \mathrm{~F}=48.54 \mathrm{~s}=0.055
\end{gathered}
$$

As in case of $C$. albicans the positive ${ }^{2} \chi$ value indicates its positive contribution to the antifungal activity of fluconazole derivatives against $A$. niger. The topological descriptor, ${ }^{2} \chi$ i.e. the second order molecular connectivity index encodes information related to the degree of stargraph likeness and linear graph likeness and takes a large value for a more linear molecule. 


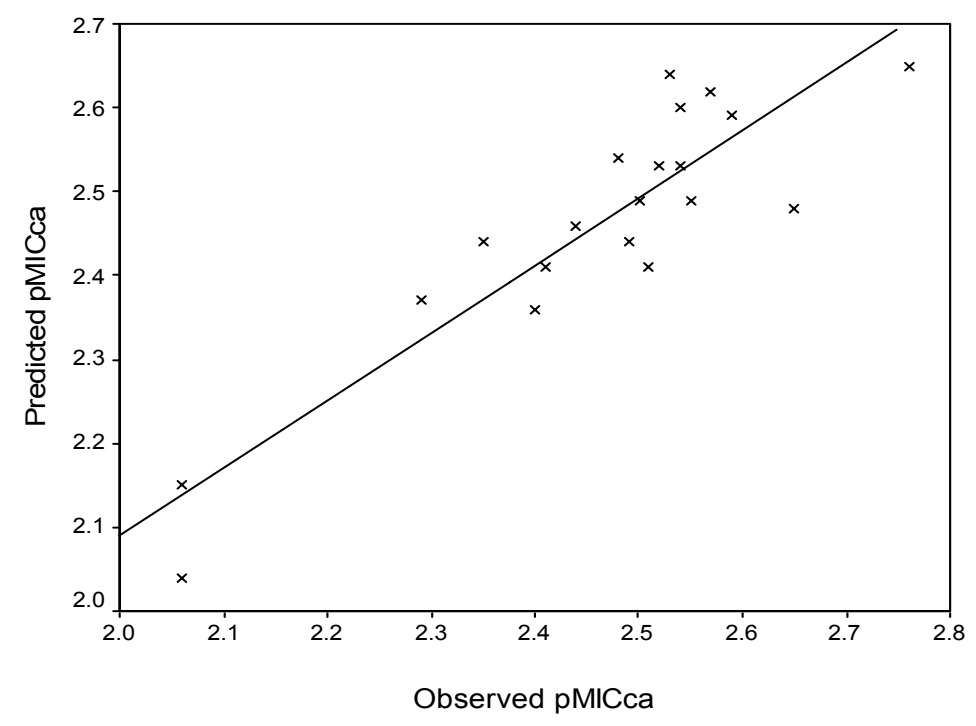

Figure 1. Plot of observed pMICca Vs QSAR calculated pMICca.

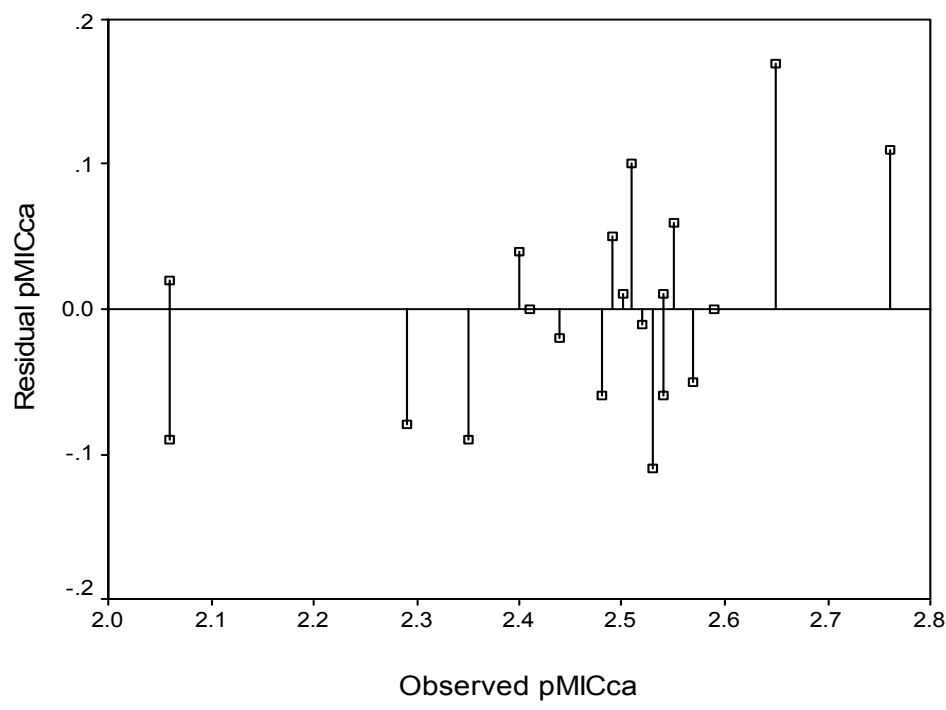

Figure 2. Plot of observed pMICca Vs Residual pMICca.

The positive coefficient of the descriptor suggests that non-branched molecules will have enhanced antifungal activity. This fact was evidenced by the antifungal activity data of fluconazole derivatives presented in Table-1, which shows that the unbranched linear fatty acid esters of fluconazole have better antifungal activity than their branched aromatic acid ester except for the case of aromatic esters having the electron donating methoxy $\left(-\mathrm{OCH}_{3}\right)$ group.

The predictive ability of the QSAR model expressed by Eq-3 is also evidenced by the low residual activities observed in Table- 4 as well as by its high $\mathrm{q}^{2}$ value $\left(\mathrm{q}^{2}=0.645, \mathrm{q}^{2}>0.5\right)$ obtained by the leave one out technique. It is worth mentioning that no outliers were observed in the present study. The statistical measures of the summarized QSAR equations described above 
portray their statistical significance and the validation parameters strongly supports their predictive potential.

\section{Conclusions}

From the results and discussion made above, we conclude that the 2-(2,4-difluorophenyl)-1,3bis(1,2,4-triazol-1-yl)propan-2-ol derivatives synthesized in the present study were more active against $A$. niger than $C$. albicans. The results of in vitro antifungal activity indicated that the compounds 6, 11 and 15 are the most effective ones. The results of the QSAR study give rise to QSAR models with good predictive ability for antifungal activity of fluconazole derivatives. Linear regression for the total data set of 20 compounds in the present study with the antifungal activity demonstrated that the electronic parameter, energy of lower unoccupied molecular orbital (LUMO) and the topological parameter, second order molecular connectivity index $\left({ }^{2} \chi\right)$ appears to be the governing factors for the antifungal potency of synthesized fluconazole derivatives.

\section{Experimental Section}

\section{General procedure for the synthesis of acid chloride. Using thionyl chloride ${ }^{37}$}

The acid $(0.16 \mathrm{~mol})$ was dissolved in thionyl chloride $(25 \mathrm{~mL})$ and refluxed for the appropriate period of time till the acid was completely converted into its corresponding acid chloride. The excess of thionyl chloride was distilled off.

\section{Using phosphorus pentachloride}

To the acid $(1 \mathrm{~g})$ in chloroform $(15 \mathrm{~mL}), 5 \mathrm{~g}$ of phosphorus pentachloride was added portion wise. The above reaction mixture was stirred for $3 \mathrm{~h}$ with a magnetic stirrer followed by its concentration under vacuum. The concentrate was filtered off and the liquid portion was used for further reaction.

\section{General procedure for the synthesis of the fluconazole ester derivatives}

Fluconazole $(0.003 \mathrm{~mol})$ in ether $(10 \mathrm{~mL})$ was added to the corresponding acid chloride $(0.005 \mathrm{~mol})$ in ether $(50 \mathrm{~mL})$ and the reaction mixture was stirred with a magnetic stirrer in cold condition $\left(0-10^{0} \mathrm{C}\right)$ for $30 \mathrm{~min}$. The solid product thus obtained was filtered off and washed with ether till the excess of acid chloride was removed. Then the crude ester was recrystallized from ethanol.

Structures of the synthesized compounds were confirmed on the basis of their spectroanalytical data. 
Analytical data for compound 2. Mp ( $\left.{ }^{\circ} \mathrm{C}\right)$ 77-80; Yield 56.5\%; IR (cm-1) 1679.7 (C=O), 1645.4 (Triazole), $1487.7(\mathrm{C}=\mathrm{C}){ }^{1} \mathrm{H}$ NMR $(\delta \mathrm{ppm}): 0.81(\mathrm{t}, 3 \mathrm{H}, \mathrm{CH}), 8.53,7.90(\mathrm{~s}, 4 \mathrm{H}, \mathrm{CH}$ of Triazole), 6.82-7.20 (m, 3H, Ar-H), 2.13-2.18 (t, 2H, C=O-CH2), $1.20(\mathrm{~m}, 14 \mathrm{H}, \mathrm{CH} 2) ;{ }^{13} \mathrm{CNMR}(\delta \mathrm{ppm})$ : $14.0,23.1,24.1,30.0,30.4,30.7,38.8,54.9$, 60.9, 78.1, 103.4, 110.8, 129.5, 131.3, 144.6, 150.2, $161.2,168.3$

Analytical data for compound 4. Mp ( $\left.{ }^{\circ} \mathrm{C}\right)$ 80-83; Yield 45.6\%; IR (cm-1) $1745.46(\mathrm{C}=\mathrm{O}), 1616.24$ (Triazole), $1558.38(\mathrm{C}=\mathrm{C}), 1423.37(\mathrm{CH}$ Str., Ar-OH); 'H NMR ( $\delta$ ppm): 8.13, $8.96(\mathrm{~s}, 4 \mathrm{H}, \mathrm{CH}$ of Triazole), 6.86-7.24 (m, 3H, Ar-H) ${ }^{13} \mathrm{CNMR}(\delta \mathrm{ppm}): 55.0,63.9,103.3,110.9,117.7,122.3$, $129.5,131.0,131.3,149.2,151.5,160.1,161.0,163.5,167.0$

Analytical data for compound 6. Mp ( $\left.{ }^{\circ} \mathrm{C}\right)$ 115-118; Yield 56.7\%; IR (cm-1) $1739.67(\mathrm{C}=\mathrm{O})$, 1616.24 (Triazole), $1512.09(\mathrm{C}=\mathrm{C})$; ${ }^{1} \mathrm{H}$ NMR $(\delta \mathrm{ppm}): 0.82(\mathrm{t}, 3 \mathrm{H}, \mathrm{CH}), 8.44,7.86(\mathrm{~s}, 4 \mathrm{H}, \mathrm{CH}$ of Triazole), $1.20\left(\mathrm{~m}, 26 \mathrm{H}, \mathrm{CH}_{2}\right), 6.85-7.14(\mathrm{~m}, 3 \mathrm{H}, \mathrm{Ar}-\mathrm{H}){ }^{13} \mathrm{CNMR}(\delta \mathrm{ppm}): 14.0,24.1,30.3$, 30.4, 30.7, 35.2, 38.8, 54.9, 60.9, 77.8, 103.4, 110.9, 129.5, 131.3, 144.5, 150.3, 161.2, 168.3

Analytical data for compound 7: $\mathrm{Mp}\left({ }^{\circ} \mathrm{C}\right)$ 97-100; Yield 53.4\%; IR (cm-1) $1710.74(\mathrm{C}=\mathrm{O})$, 1623.95 (Triazole), $1550.66(\mathrm{C}=\mathrm{C}) ;{ }^{1} \mathrm{H}$ NMR $(\delta \mathrm{ppm}): 0.79(\mathrm{t}, 3 \mathrm{H}, \mathrm{CH}), 8.22,9.03(\mathrm{~s}, 4 \mathrm{H}, \mathrm{CH}$ of Triazole), 6.85-7.19 (m, 3H, Ar-H), $1.18\left(\mathrm{~m}, 18 \mathrm{H}, \mathrm{CH}_{2}\right), 2.15\left(\mathrm{t}, 2 \mathrm{H}, \mathrm{C}=\mathrm{O}-\mathrm{CH}_{2}\right)$

Analytical data for compound 10. Mp ( $\left.{ }^{\circ} \mathrm{C}\right)$ 170-173; Yield 41.7\%; IR (cm-1) $1743.53(\mathrm{C}=\mathrm{O})$, 1618.27 (Triazole), $1504.37(\mathrm{C}=\mathrm{C}), 1683.74(\mathrm{CH}=\mathrm{CH}) ;{ }^{1} \mathrm{H}$ NMR $(\delta \mathrm{ppm}): 7.94,8.58(\mathrm{~s}, 4 \mathrm{H}, \mathrm{CH}$ of Triazole), 6.83-6.88 (m,3H,Ar-H) , 7.10-7.23 (m, 5H, ArH), 6.48- 6.53, 7.54-7.60 (dd, H, $\mathrm{CH}=\mathrm{CH}, \mathrm{J}_{\text {trans }}=22$ )

\section{Antifungal evaluation}

Using the serial dilution technique in Sabouraud dextrose broth-I.P. ${ }^{38}$ as a medium, the in vitro antifungal activity of the synthesized compounds was carried out against $C$. albicans and $A$. niger. The fluconazole derivatives were dissolved in DMSO to give a concentration of $10 \mu \mathrm{g} / \mathrm{mL}$ (stock solution). The stock solution of synthesized fluconazole derivatives were serially diluted in tubes containing $1 \mathrm{~mL}$ of sterile Sabouraud dextrose broth to get a concentration of 5 to $0.156 \mu \mathrm{g} / \mathrm{mL}$ and then inoculated with $100 \mu \mathrm{L}$ of suspension of respective organisms in sterile saline. The inoculated tubes were incubated at $37 \pm 1^{\circ} \mathrm{C}$ for $48 \mathrm{~h}$ and $25 \pm 1^{\circ} \mathrm{C}$ for $7 \mathrm{~d}$ in case of $C$. albicans and A. niger, respectively, and minimum inhibitory concentrations (MIC) were determined. From the observed MIC values, the exact MIC values were determined by making suitable dilutions of the stock solution.

\section{QSAR analysis}

The calculations of molecular descriptors of fluconazole derivatives as well as the regression analysis were carried out using the molecular package TSAR 3D version $3.3^{32}$. The details of calculation of these descriptors are available in the literature ${ }^{24-31}$ and therefore, they are not mentioned here. 


\section{Cross-validation}

The models were cross-validated by the 'leave one out' scheme ${ }^{39}$ where a model is built with N1 compounds and the $\mathrm{N}^{\text {th }}$ compound is predicted. Each compound is left out of the model derivation and predicted in turn. An indication of the performance of the model is obtained from the cross-validated (or predictive $\mathrm{q}^{2}$ ) method which is defined as

$\mathrm{q}^{2}=(\mathrm{SD}-\mathrm{PRESS} / \mathrm{SD})$.

Where SD is the sum of squares deviation for each activity from the mean. PRESS (predictive sum-of-squares) is the sum of the squared difference between the actual and that of the predicted values when the compound is omitted from the fitting process. The model with high $\mathrm{q}^{2}$ value is said to have high predictability.

\section{References and Notes}

1. Rubinstein, E. Science 1994, 264, 360.

2. Brumfit, W.; Hamilton-Miller, J. M. T.;Drug Exp. Clin. Res. 1994, 20, 215.

3. Neu, H. C. Science 1992, 257, 1064.

4. Perfect, J. R.; Lindsay, M. H.; Drew, R. H. Drug Safety 1992, 7, 323.

5. Sabra, R.; Branch, R. A. Drug Safety 1990, 5, 94.

6. Georgopapadakou, N. H.; Walsh, T. J. Antimicrob. Agents Chemother. 1996, 40, 279.

7. Ghannoum, M. A. Dermatol. Ther. 1997, 3, 104.

8. Lutwick, I. L.; Rytel, W. M. L. Am. Med. Assoc. 1979, 241, 271.

9. Fromtling, R. A. Clin. Microbial. Rev. 1988, 1, 187.

10. Godefroi, E. F.; Heeres, J.; Van Cutsem, J. J. Med. Chem.1969, 12, 784.

11. Odds, F. C.; Abbott, A. B. J. Antimicrob. Agents Chemother. 1984, 14, 105.

12. Shadomy, S.; White, S. C.; Yu, H. P. J. Infect. Dis. 1985, 152, 1249.

13. Demir-Erol, D.; Cahs, U.; Demirdamar, R.; Yulug, N.; Ertan, M. J. Pharm. Sci. 1995, 84, 462.

14. Vasanthanathan, P.; Lakshmi, M.; Babu, M. A.; Gupta, A. K..; Kaskhedikar, S. G. Chem. Pharm. Bull. 2006, 54, 583.

15. Narasimhan, B.; Kothawade, U.R.; Pharande, D.S.; Mourya, V.K.; Dhake, A.S. Indian J. Chem. 2003, 42B, 2828.

16. Narasimhan, B.; Belsare, D.; Pharande, P.; Mourya, V.; Dhake, A. Eur. J. Med. Chem. 2004, 39, 827.

17. Narasimhan, B.; Mourya, V.; Dhake, A. Biorg. Med. Chem. Lett. 2006, 16, 3023.

18. Narasimhan, B.; Mourya, V. K.; Dhake, A. S. Khim.-Farm. Zh, 2007, 3, 120.

19. Gangwal, N.A.; Narasimhan, B.; Mourya, V.K.; Dhake, A.S. Indian J. Het. Chem, 2003, 12, 201.

20. Narasimhan, B.; Kumari, M.; Dhake, A.; Sundaravelan, C. Arkivoc 2006, xiii, 73.

21. Kumar, A.; Narasimhan, B.; Kumar, D. Biorg. Med. Chem. 2007, 15, 4113. 
22. Cappucino, J. G.; Sherman, N. Microbiology-A Laboratory Manual; Addison Wesley: California , 1999; pp 263.

23. Hansch, C.; Leo, A. Exploring QSAR, Fundamentals and Applications in Chemistry and Biology; ACS: Washington, 1995.

24. Hansch, C.; Fujita, T. J. Am. Chem. Soc. 1964, 86, 1616.

25. Hansch, C.; Leo,A.; Unger, S. H.; Kim, K. H.; Nikaitani, D.; Lien, E. J. J. Med. Chem. 1973, 16, 1207.

26. Kier, L. B.; Hall, L. H. Molecular Connectivity in Chemistry and Drug Research; Academic Press: New York , 1976; 129.

27. Randic, M. J. Am. Chem. Soc. 1975, 97, 6609.

28. Balban, A. T. Chem. Phys. Lett. 1982, 89, 399.

29. Wiener, H. J. Am. Chem. Soc. 1947, 69, 17.

30. Sharma, P.; Rane, N.; Gurram, V. K. Bioorg. Med. Chem. Lett. 2004, 14, 4185.

31. Randic, M. Croat. Chem. Acta 1993, 66, 289.

32. TSAR 3D version 3.3, Oxford Molecular Limited, 2000.

33. Narasimhan, B.; Kumari, M.; Jain, N.; Dhake, A.; Sundaravelan, C. Bioorg. Med. Chem. Lett. 2006, 16, 4951.

34. van de Waterbeend, H.; Carter, B. F.; Grassy, G.; Kubinyi, H.; Martin, Y. C.; Tute, M. S., Willet, P. Albany Molecular Research, Tech. Rep.. 1998, Vol 2.

35. Kumar, P. M.; Karthikeyan, C.; Moorthy, N. S. H.; Trivedi, P. Chem. Pharm. Bull. 2006, 54, 1586.

36. Golbraikh, A.; Tropsha, A.; J. Mol. Graphics Model. 2002, 20, 269.

37. Kumar, P.; Pathak, P. K.; Kushwaha, B. S. Asian J. Chem. 2006, 18(2), 1055.

38. Pharmacopaeia of India ; Ministry of Health Department: Govt. of India : New Delhi , 1996, Vol-II, pp A-88.

39. Agrawal, V. K.; Singh, J.; Mishra, K. C.; Khadikar, P. V.; Jaliwala, Y. A. Arkivoc 2006, ii, 162. 